\title{
An illustrated key to the fiddler crabs (Crustacea, Decapoda, Ocypodidae) from the Atlantic coast of Brazil
}

\author{
Setuko Masunari', Salise Brandt Martins', André Fernando Miyadi Anacleto' \\ I Laboratory for Crustacean Research UFPR, Department of Zoology, Federal University of Paraná, Curitiba, \\ Paraná State, Brazil \\ Corresponding author: Setuko Masunari (setmas@ufpr.br)
}

Academic editor: I. S. Wehrtmann | Received 31 March 2020 | Accepted 30 April 2020 | Published 22 June 2020

http://zoobank.org/D161D933-3424-4585-8022-ABC474BE73DB

Citation: Masunari S, Martins SB, Anacleto AFM (2020) An illustrated key to the fiddler crabs (Crustacea, Decapoda, Ocypodidae) from the Atlantic coast of Brazil. ZooKeys 943: 1-20. https://doi.org/10.3897/zookeys.943.52773

\begin{abstract}
Fiddler crabs are one of the most notable animal groups in Brazilian estuarine environments, due to their high density and characteristic waving of males. An illustrated key to the ten species recorded as far in the country is provided using only clearly visible characters of males. Furthermore, additional recognition characters, information about geographic distribution and biology of each species are presented. Most examined crabs were collected in Guaratuba Bay, southern Brazil.
\end{abstract}

\section{Keywords}

Biological notes, distribution, mangrove, recognition characters, tidal flats

\section{Introduction}

Studies on fiddler crabs began more than 300 years ago, certainly because the observers were attracted to the immense claw of males that were tirelessly waving in a typical movement and rhythm. Fiddler crabs are semi-terrestrial decapod crustaceans and inhabit shaded substrates of mangrove forest or sunny tidal flats adjacent to it. During high tides they hide in individual burrows that are the center of a fiddler crab life (Crane 1975).

Ten species of fiddler crabs are known from the Brazilian Atlantic coast (Melo 1996), with the newest species described more than 30 years ago by von Hagen (1987). 
Brazilian population studies, however, began only at the beginning of the present century, and a great deal of knowledge was generated since then (see partial review in Ribeiro and Bezerra 2014).

Despite the valuable identification keys for Brazilian fiddler crabs elaborated by Crane (1975), Melo (1996) and Bezerra (2012), the number of misidentifications found in various scientific collections is remarkable (see these three authors). The aim of this paper is to present an illustrated identification key for the species of fiddler crabs occurring at the Brazilian Atlantic coast in order to aid undergraduate students and early researchers.

\section{Materials and methods}

Ten species of fiddler crabs recorded along Brazilian coast were analyzed, each one represented by numerous individuals. Most of them (seven species) were collected in various habitats of Guaratuba Bay, municipality of Guaratuba, southern Brazil: $M i$ nuca burgersi (Holthuis, 1967), M. mordax (Smith, 1870), M. rapax (Smith, 1870), Leptuca leptodactyla (Rathbun, 1898), L. thayeri (Rathbun, 1900), L. uruguayensis (Nobili, 1901), and Uca maracoani (Latreille, 1802-1803). These crabs were deposited in the Natural Museum of Natural History of Capáo da Imbuia located in Curitiba, Paraná State, southern Brazil. The remaining three species were obtained from other locations in Brazil: L. cumulanta (Crane, 1943) from Natal (Rio Grande do Norte state, northeastern Brazil), M. vocator (Herbst, 1804) from Cananeia (São Paulo state, southeastern Brazil) and M. victoriana (von Hagen, 1987) from Guarapari (Espírito Santo state, southeastern Brazil); the specimens of the latter species were deposited at the Museum of Zoology of University of São Paulo.

The illustrated key was elaborated as simple as possible, and only clearly visible characters were selected. The key is exclusively based on adult male individuals, as they are provided with the diagnostic characters of the species. As fiddler crabs have gregarious habits, male individuals are hardly absent in the populations.

Line drawings were prepared using a drawing tube attached to a stereoscopic microscope. The systematic nomenclature was based on Shih et al. (2016) and morphological terminology follows Crane (1975). Additional practical characters were added in the item "Recognition characters". Information on geographical distribution of the species (Table 1) was based on Crane (1975), Mendes and Couto (2001), Koch et al. (2005), Baptista and Calado (2007), Bezerra (2012), Thurman et al. (2013), Pillon (2014), Martins (2018), and Silva (2019). Furthermore, the occurrence of Uca maracoani at coast of Santa Catarina state was based on the observation of S.B. Martins (pers. comm.).

The pile, an important morphological feature, is a wooly pubescence on the surface of carapace and ambulatory legs of some species. It is a somewhat difficult to be recognized by beginners, especially in crabs that were preserved in liquids. Drying the specimens in the open air is a practical clue to facilitate the visualization: the piles appear as clear and rough patches on the darkened surface of the carapace or ambulatory legs. It is highly recommended that beginners learn to distinguish these piles, since some morphologically similar species can be easily identified by observing the distribution of these patches. 
Table I. Geographic distribution of the fiddler crab species along the Atlantic coast of Brazil. The states were organized by increasing southern latitudes (from left to right), except Amapá that is located northern to Equator. Abbreviations: $\mathrm{AL}=$ Alagoas, $\mathrm{AP}=$ Amapá, $\mathrm{BA}=\mathrm{Bahia}, \mathrm{CE}=$ Ceará, $\mathrm{ES}=$ Espírito Santo, $\mathrm{MA}$ = Maranhão, $\mathrm{PA}=$ Pará, $\mathrm{PB}=$ Paraíba, $\mathrm{PE}=$ Pernambuco, $\mathrm{PI}=$ Piauí, $\mathrm{PR}=$ Paraná, $\mathrm{RJ}=$ Rio de Janeiro, RN = Rio Grande do Norte, RS = Rio Grande do Sul, SC = Santa Catarina, SE = Sergipe, SP = São Paulo. Black circle $=$ occurrence recorded; white circle $=$ probable occurrence but not officially recorded; black square $=$ presence of mangrove .

\begin{tabular}{|c|c|c|c|c|c|c|c|c|c|c|c|c|c|c|c|c|c|c|c|}
\hline States of Brazil & AP & \multirow{12}{*}{ 总 } & PA & MA & PI & $\mathrm{CE}$ & RN & PB & PE & AL & SE & BA & ES & RJ & \multirow{12}{*}{ 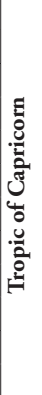 } & SP & PR & SC & RS \\
\hline Mangrove & - & & - & - & $\square$ & - & - & - & - & - & - & - & ! & ! & & ! & - & - & \\
\hline Minuca mordax & $\bullet$ & & $\bullet$ & $\bullet$ & $\circ$ & $\bullet$ & $\bullet$ & o & $\bullet$ & $\bullet$ & $\cdot$ & $\bullet$ & $\bullet$ & $\cdot$ & & $\cdot$ & $\bullet$ & - & $\cdot$ \\
\hline Minuca rapax & $\bullet$ & & $\bullet$ & $\bullet$ & $\bullet$ & $\bullet$ & $\bullet$ & • & $\bullet$ & $\bullet$ & • & $\bullet$ & $\bullet$ & $\cdot$ & & $\cdot$ & $\bullet$ & $\bullet$ & \\
\hline Uca maracoani & $\bullet$ & & $\bullet$ & $\bullet$ & $\circ$ & $\bullet$ & $\cdot$ & $\bullet$ & $\bullet$ & $\cdot$ & $\cdot$ & $\bullet$ & $\bullet$ & $\bullet$ & & $\cdot$ & $\bullet$ & $\bullet$ & \\
\hline Leptuca leptodactyla & & & $\bullet$ & $\bullet$ & $\cdot$ & $\bullet$ & $\cdot$ & $\cdot$ & $\bullet$ & $\bullet$ & $\cdot$ & $\bullet$ & $\cdot$ & $\cdot$ & & $\cdot$ & $\bullet$ & $\cdot$ & \\
\hline Leptuca thayeri & & & $\bullet$ & $\bullet$ & $\circ$ & $\bullet$ & $\bullet$ & $\bullet$ & $\bullet$ & $\bullet$ & $\cdot$ & $\bullet$ & $\bullet$ & $\bullet$ & & $\cdot$ & $\bullet$ & $\bullet$ & \\
\hline Minuca burgersi & & & $\cdot$ & $\bullet$ & $\circ$ & $\bullet$ & $\cdot$ & $\bullet$ & $\cdot$ & $\cdot$ & $\cdot$ & $\cdot$ & $\cdot$ & $\bullet$ & & $\cdot$ & $\cdot$ & $\cdot$ & \\
\hline Minuca vocator & $\bullet$ & & $\bullet$ & $\bullet$ & $\circ$ & $\bullet$ & $\circ$ & $\bullet$ & $\bullet$ & $\bullet$ & - & $\bullet$ & $\circ$ & $\bullet$ & & $\cdot$ & & & \\
\hline Leptuca cumulanta & $\bullet$ & & $\bullet$ & $\bullet$ & $\circ$ & $\bullet$ & $\cdot$ & $\bullet$ & $\bullet$ & $\bullet$ & $\cdot$ & $\cdot$ & $\circ$ & $\cdot$ & & & & & \\
\hline Minuca victoriana & & & & & & $\bullet$ & & & $\bullet$ & & & $\bullet$ & $\bullet$ & $\bullet$ & & $\cdot$ & & & \\
\hline Leptuca uruguayensis & & & & & & & & & & & & & & $\bullet$ & & $\cdot$ & $\cdot$ & $\bullet$ & $\bullet$ \\
\hline
\end{tabular}

\section{Key to the species of fiddler crabs from Brazil}

1 Narrow front, width less than or equal to $15 \%$ of front-orbital breadth (Fig. 1) (big and medium-sized crabs)

- Wide and triangular front, width more than $15 \%$ of front-orbital breadth (Fig. 1B) (medium-sized and small crabs)
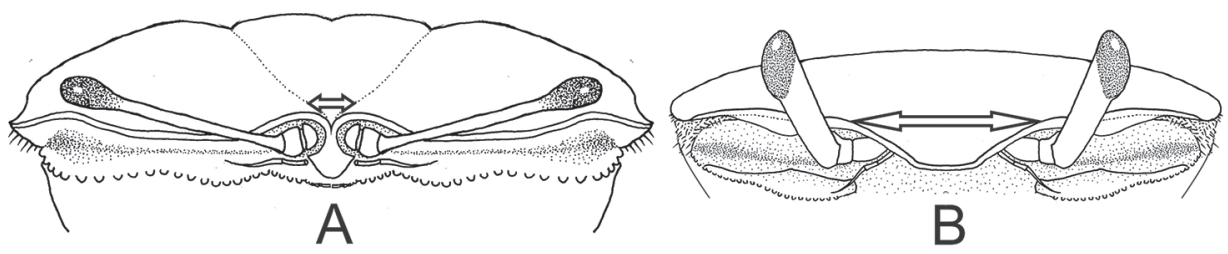

Figure I. Carapace, frontal view. A Uca maracoani: spatulate and narrow front (seta) B Minuca burgersi: triangulate and wide front (seta).

2 Spatulate front (Fig. 1A), width equal to or less than $4 \%$ of front-orbital breadth; carapace with bare dorsal surface (Fig. 2A); male major claw with flat fingers like two blades (Fig. 2B) (big crabs, adults can reach up to $45.0 \mathrm{~mm}$ carapace width CW)

Uca maracoani

- Triangular front, base ca. $15 \%$ of front-orbital breadth; patches of pile (= woolly pubescence, easily detached) on dorsal surface of carapace (Fig. 2C) 
and on ambulatory legs; major claw of males with cylindrical fingers (Fig. 2D) (medium-sized crabs, adult males can reach up to $28.4 \mathrm{~mm}$ carapace width)

Leptuca thayeri
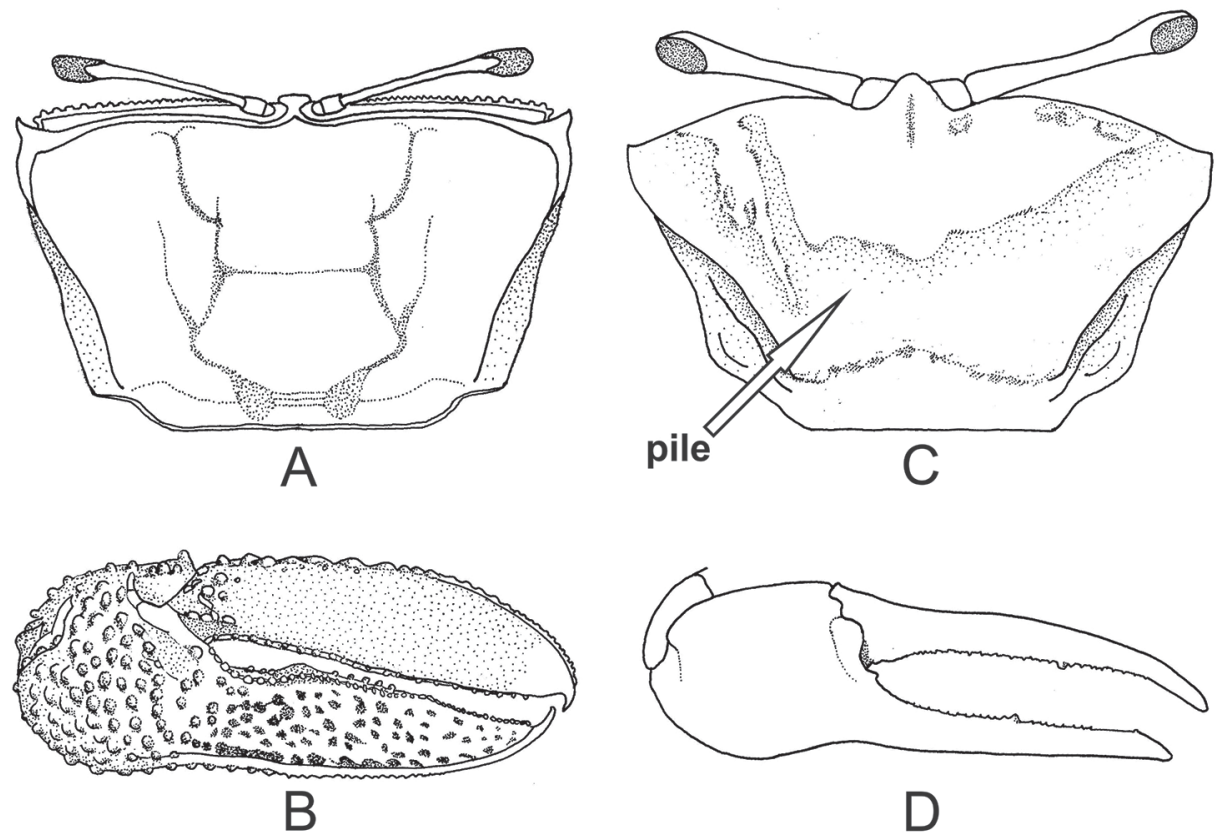

Figure 2. Uca maracoani. A carapace with bare surface, dorsal view B male major claw with flat fingers, frontal view. Leptuca thayeri $\mathbf{C}$ carapace mostly covered with pile (seta) D male major claw with cylindrical fingers, frontal view.

3 Carapace provided with major and minor pairs of postero-lateral striae (Figs 3A, 5B, 6A, 8A, C) (medium-sized crabs, adult males with maximum $\mathrm{CW}$ $19.0-29.0 \mathrm{~mm})$

- $\quad$ Carapace provided with a single pair of postero-lateral striae (Figs 10A, 11A,

C) (small crabs, adult males with maximum of $15.0 \mathrm{~mm} \mathrm{CW}$ ) ....................8

4 Exuberant pile on the dorsal surface of the carapace forming a typical pattern (Fig. 3A) and on all segments of ambulatory legs except dactyl (Fig. 3B) ......

Minuca vocator

- $\quad$ Carapace with discrete pile or without any, but segments of ambulatory legs (at least from $1^{\text {st }}$ to $3^{\text {rd }}$ pairs) with pile (Figs $4 \mathrm{~A}, \mathrm{~B}$ ) 5 


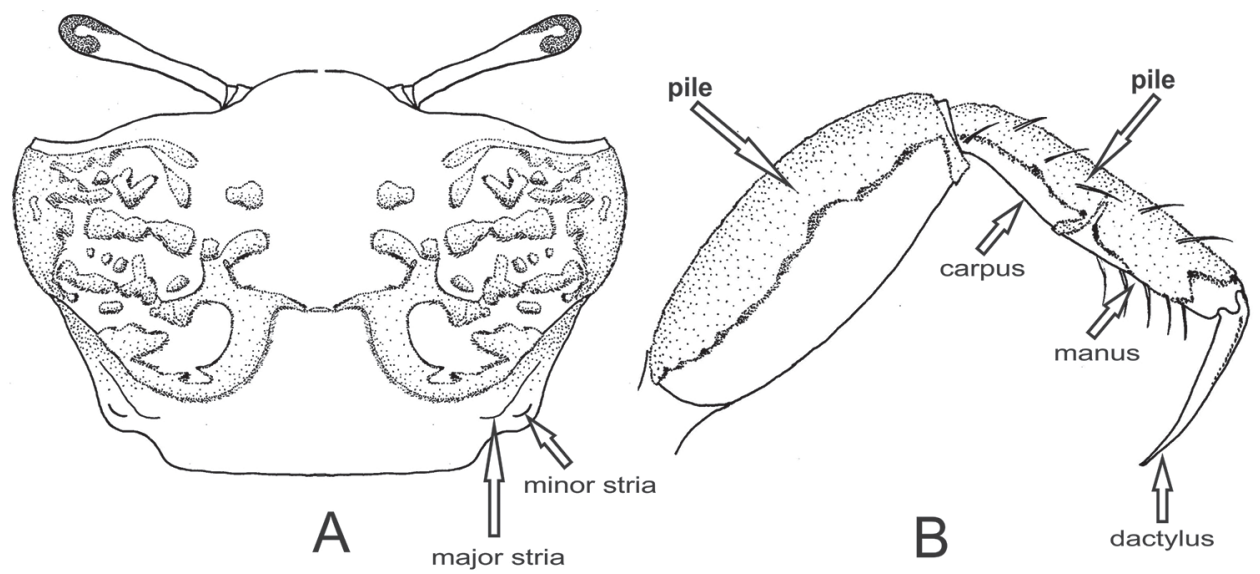

Figure 3. Minuca vocator. A carapace with pile forming a typical pattern, dorsal view $\mathbf{B}$ third ambulatory leg with pile on dorsal surface of all segments except dactylus (setae), posterior view.

$5 \quad$ Male major chela provided with a short and straight depression filled with pile at the base of pollex (Fig. 5C); discrete pile on carpus and manus (adult male CW maximum $19.1 \mathrm{~mm}$ )

Minuca victoriana

- $\quad$ Male major chela without any depression at the base of pollex (Fig. 6B) (adult male CW up to $29.0 \mathrm{~mm}$ ) .......................................................................6

6 Pile on dorsal surface of carpus and merus and around the entire surface of manus of ambulatory legs ( $1^{\text {st }}$ to $3^{\text {rd }}$ pairs) (Fig. $4 \mathrm{~A}$ )

Minuca mordax

- $\quad$ Pile limited to dorsal surface of carpus and manus of ambulatory legs ( $1^{\text {st }}$ to $3^{\text {rd }}$ pairs); merus without pile (Fig. 4B) .7

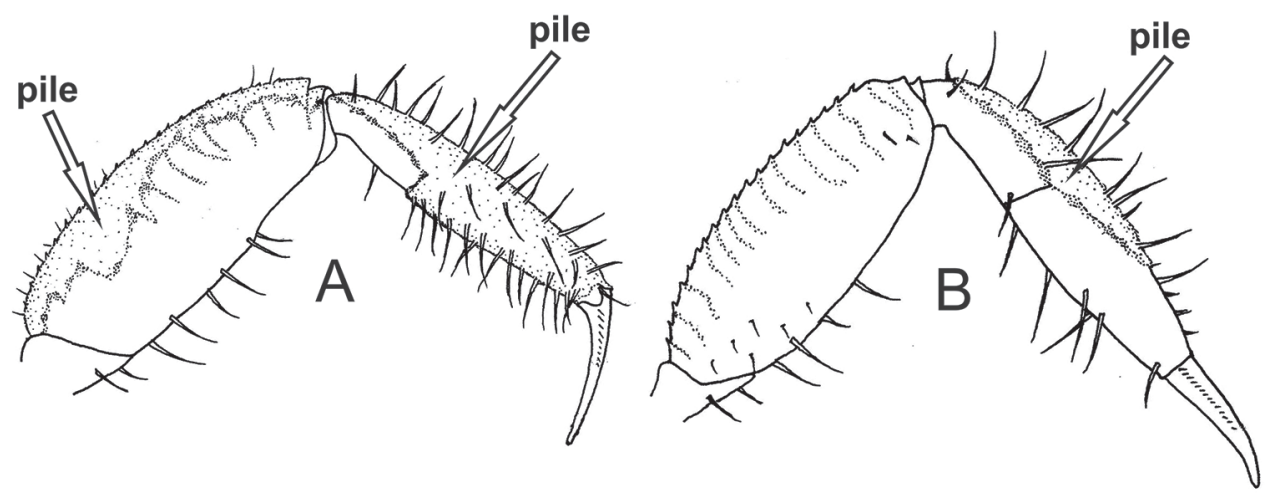

Figure 4. Third ambulatory leg, posterior view. A Minuca mordax with pile on dorsal surface of merus (seta) and carpus and all around surfaces of manus (seta) B Minuca burgersi with pile limited to dorsal surface of carpus and manus (seta). 


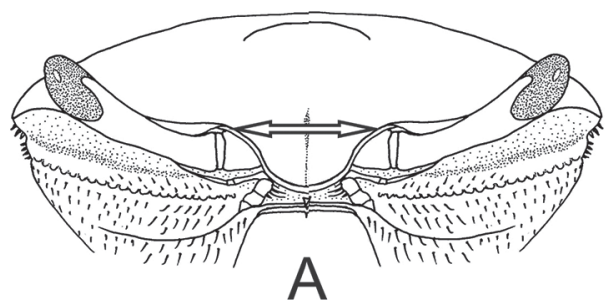

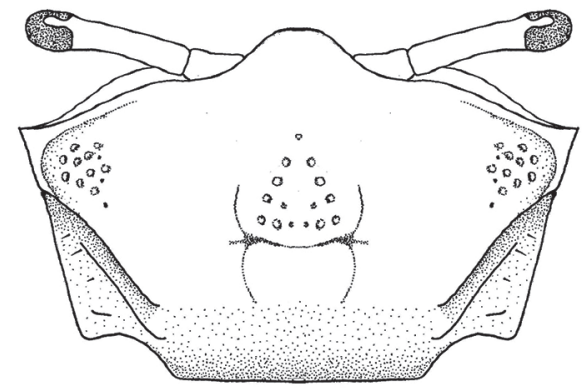

B

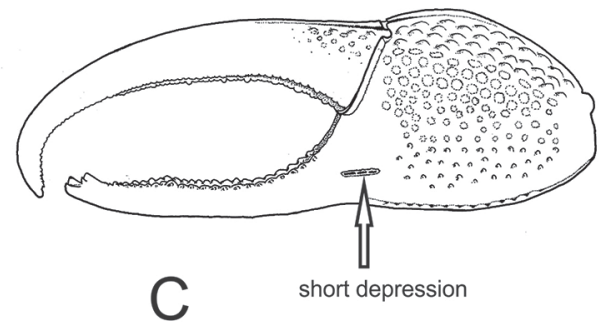

Figure 5. Minuca victoriana. A carapace with moderately large front, frontal view B carapace with two pairs of postero-lateral striae, dorsal view $\mathbf{C}$ male major claw with a short depression at the base of pollex (seta), frontal view.
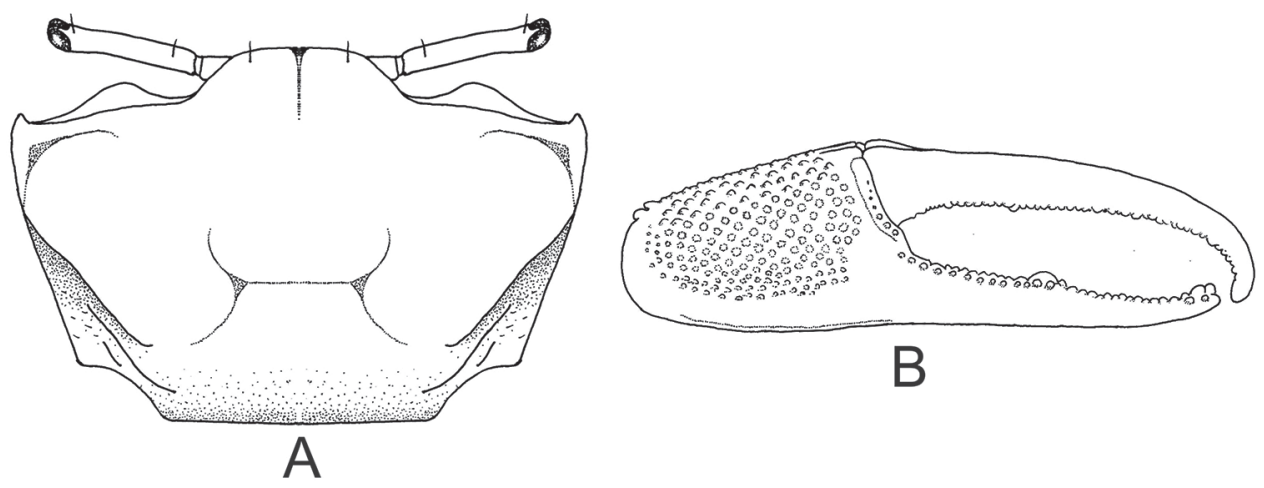

Figure 6. Minuca mordax. A carapace without pile and with two pairs of postero-lateral striae, dorsal view $\mathbf{B}$ male major claw, frontal view.

$7 \quad$ Ambulatory legs with wide merus and dorsal margin convex; merus of last pair of ambulatory legs more than two times wider than respective carpus in its maximum breadth (Fig. 7A)

Minuca rapax

- Ambulatory legs with narrow merus and dorsal margin almost straight; merus of last pair of ambulatory legs less than two times wider than respective carpus in its maximum breadth (Fig. 7B) 

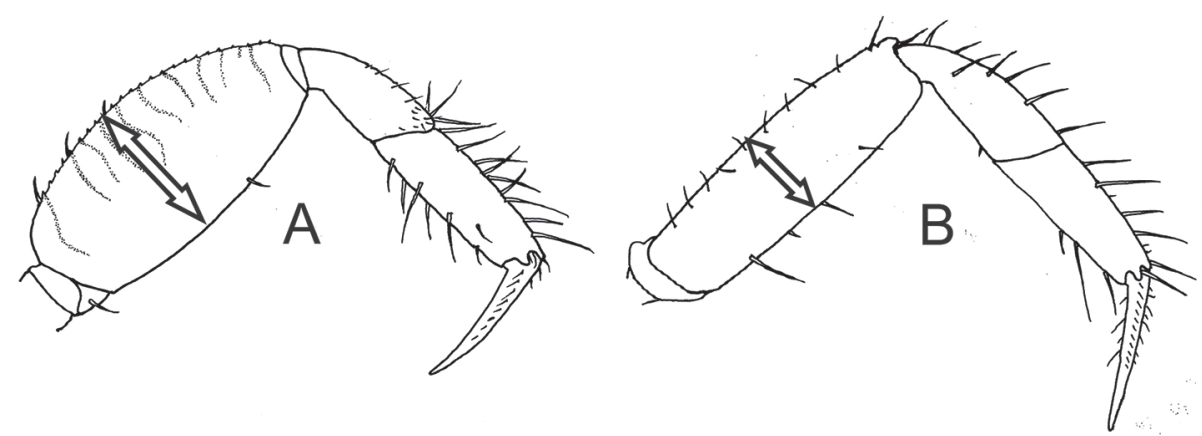

Figure 7. Last ambulatory legs, posterior view. A Minuca rapax, wide merus (seta). B Minuca burgersi, narrow merus (seta).
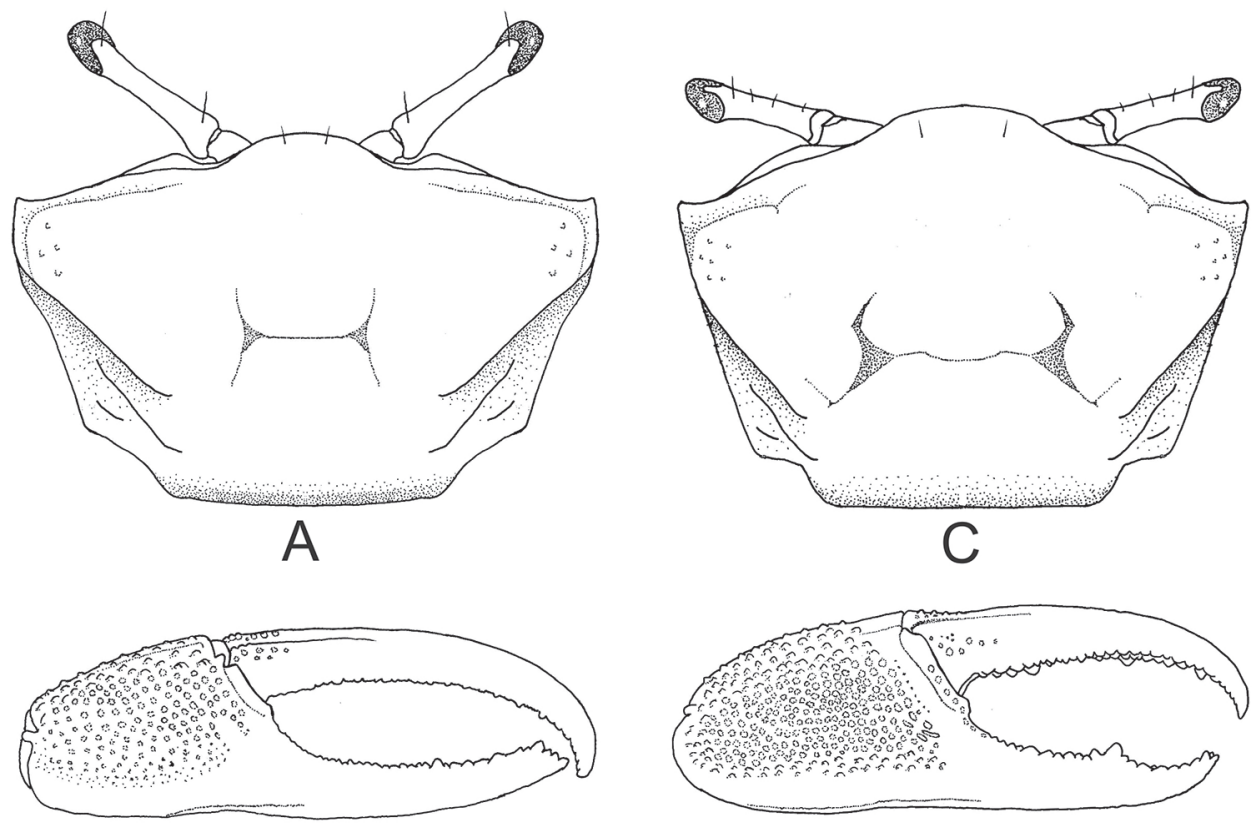

B

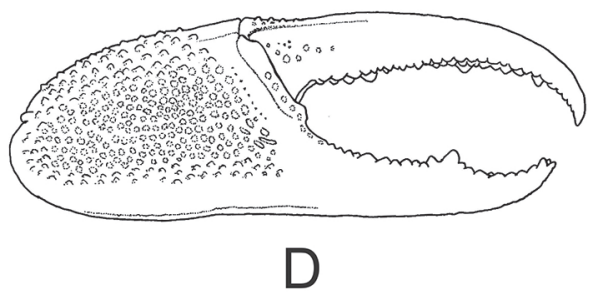

Figure 8. Minuca rapax. A carapace with two pairs of postero-lateral striae, dorsal view B male major claw, frontal view. Minuca burgersi C Carapace with two pairs of postero-lateral striae, dorsal view D male major claw, frontal view. 

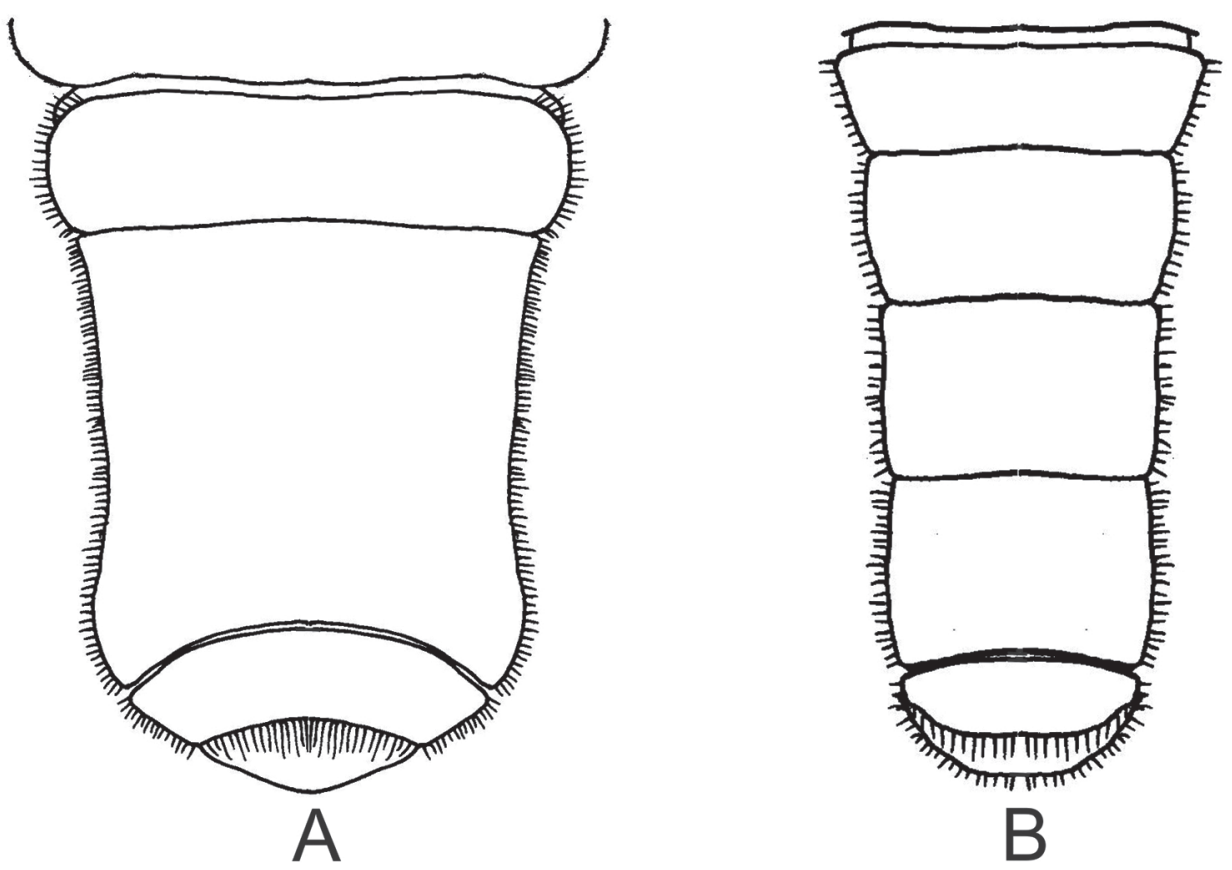

Figure 9. Abdomen of male, ventral view. A Leptuca leptodactyla, middle somites fused B Leptuca cumulanta, all somites distinct.
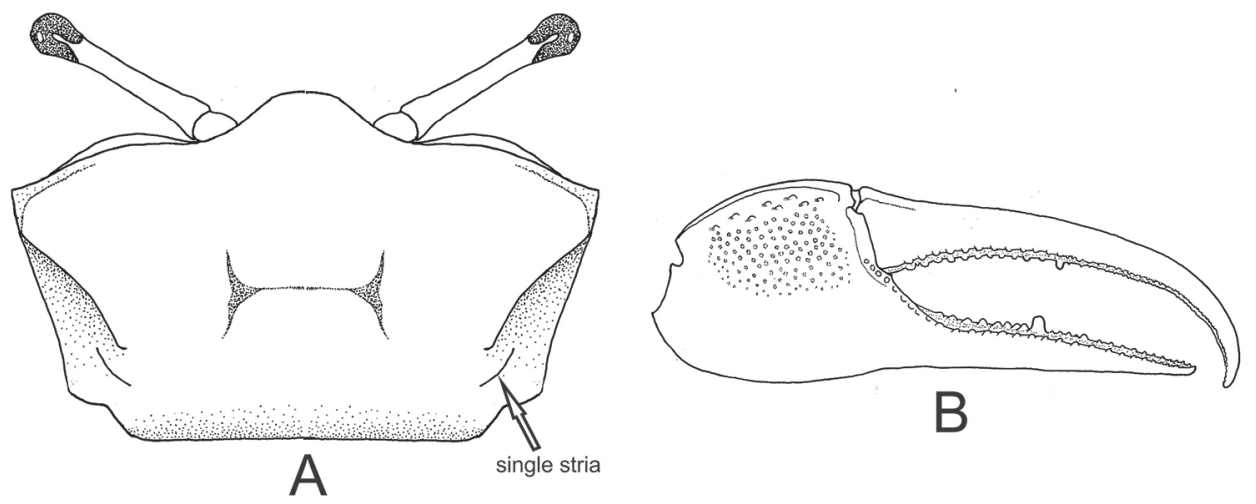

Figure 10. Leptuca cumulanta. A carapace with a pair of postero-lateral striae (seta), dorsal view B male major claw, frontal view. 
$9 \quad$ Manus of major claw provided with a long groove on dorsal surface following its margin, mostly filled with dirt (Fig. 11B); length of major claw fingers ca. 1.3 times longer than manus Leptuca uruguayensis - $\quad$ Manus of major claw without any groove on dorsal surface (Fig. 11D); length of major claw fingers at least 1.6 times longer than manus
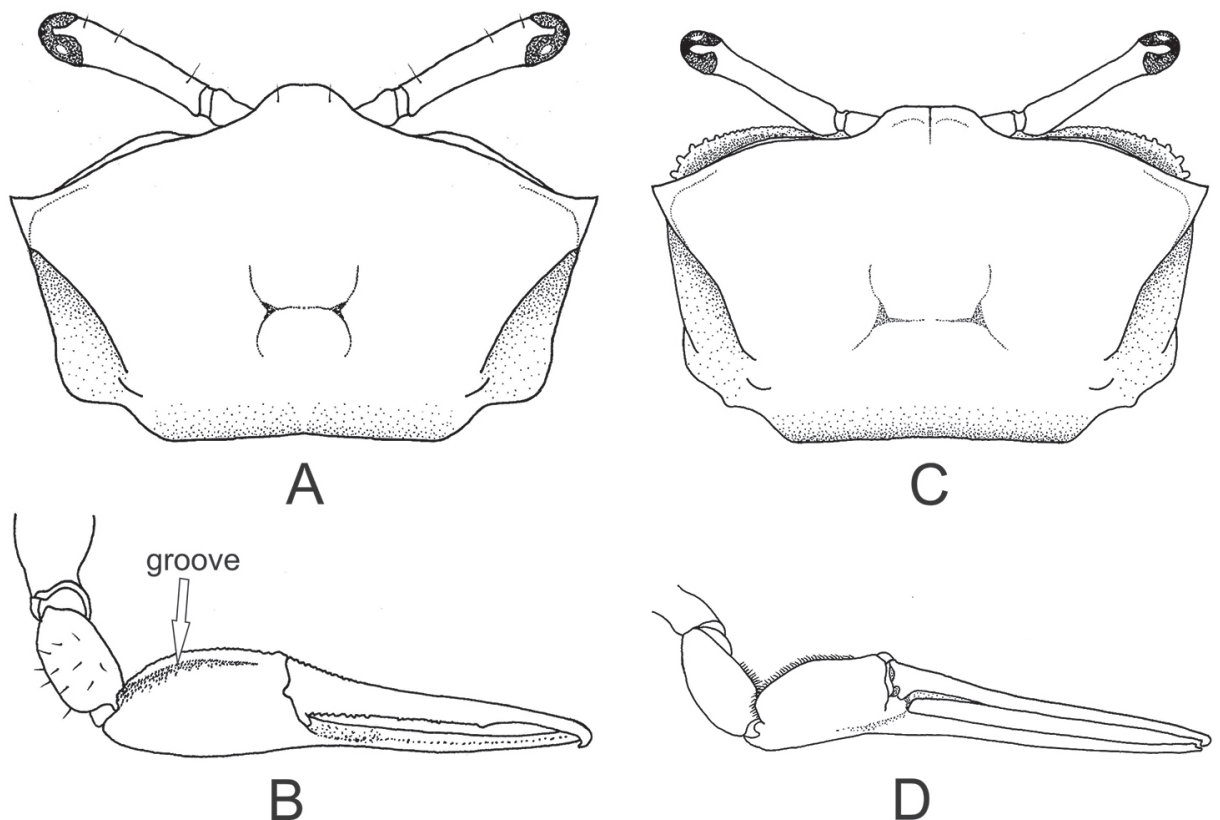

Figure II. Leptuca uruguayensis. A carapace with a pair of postero-lateral striae, dorsal view B male major claw with dorsal groove (seta), dorso-frontal view. Leptuca leptodactyla $\mathbf{C}$ carapace with a pair of postero-lateral striae, dorsal view $\mathbf{D}$ male major claw without dorsal groove, dorso-frontal view.

\section{Taxonomy}

\section{Subfamily Gelasiminae}

\section{Minuca burgersi (Holthuis, 1967)}

Figures 1B, 4B, 7B, 8C, D

Recognition characters. Carapace pentagonal moderately arched in the anteroposterior direction and dorsal surface without pile (Fig. 8C). Dorso-lateral margins well-marked and converging posteriorly; major and minor pairs of postero-lateral striae clearly visible (Fig. 8 C). Front triangular and very wide making up from $36 \%$ to $41 \%$ of the front- 
orbital breadth (Fig. 1B). Male major claw manus covered by small tubercles and provided with a strong groove (sometimes filled with dirt) on dorsal surface following the dorsal margin; fingers thick and slightly flattened; dactyl little longer than manus; pollex and dactyl curved forming a large gap (Fig. 8D). First three ambulatory legs with pile (= woolly pubescence) limited to dorsal surface of carpus and manus (Fig. 4B, setae), absent in ventral margin; all ambulatory legs with narrow merus and dorsal margin almost strait; last pair of ambulatory legs without piles and merus less than two 1.5 times wider than respective carpus in its maximum breadth (Fig. 7B). Male abdominal segments never fused. Medium-sized species and one of the smallest in the genus; males' carapace width (CW) up to $19.0 \mathrm{~mm}$ in a population from Fortaleza, CE, Brazil (Crane 1975).

Biological notes. The species reproduces year-round in the population of Ubatuba, southeastern Brazil (Benetti et al. 2007). It occurs in oligohaline and mesohaline areas and on sandy substrate although in low densities (Masunari 2006; Thurman et al. 2013).

Remarks. The species is morphologically close to its congeners $M$. rapax and M. mordax; the distinguishing characters among these species are treated in the subsequent items.

\section{Subfamily Gelasiminae}

\section{Minuca mordax (Smith, 1870)}

Figures $4 \mathrm{~A}, 6 \mathrm{~A}, \mathrm{~B}$

Recognition characters. Carapace pentagonal moderately arched and with naked dorsal surface, without pile (Fig. 6A). Dorso-lateral margins well marked and strongly convergent posteriorly; major and minor pairs of postero-lateral striae clearly visible (Fig. 6A). Front triangular and very wide making up between 34\% to $38 \%$ of the frontorbital breadth. Male major claw with manus covered by tubercles and with strong groove on dorsal surface; fingers thick and slightly flattened; dactyl ca. 1.5 times the manus length; pollex almost straight with tip curved upwards; dactyl strongly arched ending in a curved downward tip; fingers form a wide gap (Fig. 6B). Ambulatory legs with narrow merus and dorsal margin almost strait; $1^{\text {st }}$ to $3^{\text {rd }}$ ambulatory legs with pile limited to dorsal surface of merus (weakly) and carpus (strongly), but all around the manus (strongly) (Fig. 4A); last pair with scant pile on merus, carpus and manus. Male abdominal segments never fused. Medium-sized crab: males' CW up to $26.1 \mathrm{~mm}$ in a population from mangrove of Itajaí River, southern Brazil (Scalco et al. 2016).

Biological notes. Ovigerous females were collected inside burrows that were ornamented with poorly structured chimney at Guaratuba Bay, southern Brazil, during a warm month (November) (Martins et al. 2016). The duration of the reproductive period of this species, however, is still unknown. The species dispersal is larval retention type: after larval period in the pelagic environment of the bay, megalopae return to terrestrial areas, by colonizing mats of red algae that grow on humid substrates. Early juveniles seek shelter among entangled thalli of these red algae, and after molting they migrate to soft muddy substrate (S.B. Martins, pers. comm.). Adults live on consolidated sandy banks of rivers flowing into Guaratuba Bay, forming large populations (Masunari 2006). 
Remarks. The most conspicuous morphological character of $M$. mordax is the presence of piles covering the entire surface (dorsal, lateral and ventral) of the manus of $1^{\text {st }}$ to $3^{\text {rd }}$ ambulatory legs. This feature allows to easily distinguish $M$. mordax from two other closely related species, $M$. burgersi and $M$. rapax. As no piles are present on carapace of these three species, they hardly will be confused with Leptuca thayeri or Minuca vocator. In the field, these species can also be distinguished by its respective habitat: while $M$. mordax is mostly found in freshwater or oligohaline areas such as river banks and tidal flats near river mouth, $M$. rapax and $M$. burgersi are mainly found in mesohaline tidal flats, often in co-occurrence.

\section{Subfamily Gelasiminae}

\section{Minuca rapax (Smith, 1870)}

Figures 7A, 8A, B

Recognition characters. Carapace pentagonal moderately arched and provided with small and scarce tubercles in the antero-lateral corner (Fig. 8A); some individuals have pile on H-form depression. Dorso-lateral margins well marked and strongly convergent posteriorly (more pronounced in males); major and minor pairs of postero-lateral striae clearly visible (Fig. 8A). Front triangular and very wide making up 30\% to 36\% of the front-orbital breadth. Male major claw with manus covered with tubercles and provided with strong groove dorsally; fingers thick and slightly flattened; dactyl ca. 1.5 times longer than manus; pollex and dactyl strongly curved forming a large gap (Fig. $8 \mathrm{~B})$. Pile limited the dorsal surface of carpus and manus in the first three ambulatory legs; these legs with enlarged merus (especially the $2^{\text {nd }}$ and $3^{\text {rd }}$ ), dorsal margin convex and dorsal surface with striated ornaments; last leg without piles and merus more than two times wider the respective carpus in their maximum breadth (Fig. 7A, seta). Male abdominal segments never fused. Medium-sized crabs, male CW up to $28.3 \mathrm{~mm}$ and female up to $27.3 \mathrm{~mm}$ in a population from Itamambuca mangrove, Ubatuba, southeastern Brazil (Castiglioni and Negreiros-Fransozo 2004).

Biological notes. The species reproduces year-round in the populations from northern and southeastern Brazil (Koch et al. 2005, Castiglioni and Negreiros-Fransozo 2006; Costa and Soares-Gomes 2009). It prefers mesohaline to euhaline areas but it can be found in a wide range of salinities, from oligohaline to euhaline; the preferred substrate is firm sandy to silty clay with humus or clayed silt (Thurman et al. 2013).

Remarks. Morphologically very similar to $M$. burgersi and M. mordax. Minuca rapax can be distinguished from $M$. mordax in not having a pile around the entire surface of manus of $1^{\text {st }}$ to $3^{\text {rd }}$ ambulatory legs. The distinction between $M$. rapax and $M$. burgersi, however, requires an extra attention: both species have piles limited to the dorsal surface of carpus and manus of $1^{\text {st }}$ to $3^{\text {rd }}$ ambulatory legs. The easiest way to distinguish these two species is to compare the last ambulatory leg: while $M$. rapax has a wide merus with convex dorsal margin (Fig. 7A), that of $M$. burgersi is narrow and its margins are almost parallel (Fig. 7B). 


\section{Subfamily Gelasiminae}

\section{Minuca victoriana (von Hagen, 1987)}

Figure 5A-C

Recognition characters. Carapace pentagonal moderately arched and provided with few tubercles on the surface of antero-lateral corners and on mesogastric area (Fig. 5A). Dorso-lateral margins well marked and strongly convergent posteriorly; major and minor pairs of postero-lateral striae clearly visible (Fig. 5B). The discrete pile on the carapace described by von Hagen (1987) was not observed in the specimens examined in the present study. Front triangular and moderately large making up ca. $22 \%$ of frontorbital breath (Fig. 5A, seta). Male major claw with manus covered with tubercles and provided with strong groove on dorsal margin filled with pile; fingers thick and slightly flattened; dactyl ca. 1.8 times longer than manus; pollex and dactyl strongly curved forming a large gap; a short and straight depression filled with pile at the base of pollex (Fig. 5C, seta). Scant pile on dorsal surface of carpus and manus of the first three pair of ambulatory legs. Male abdomen somites not fused. Medium-sized species and one of the smallest in the genus; males' carapace width (CW) up to $19.1 \mathrm{~mm}$ in a population from Vitória, Espírito Santo state, southeastern Brazil (von Hagen 1987).

Biological notes. Although with a wide geographical distribution, the species forms sparse populations constituted by small individuals in impacted mangroves of southeastern Brazil (Bedê et al. 2008). In tropical mangroves, these crabs form relatively dense populations, reaching larger $\mathrm{CW}$ than in southern population and preferring muddy substrates. The recruitment of juveniles occurs continuously; however, the reproductive period of the species is still unknown (Castiglioni et al. 2010).

Remarks. The easiest way to recognize this species is to examine the presence of a short and straight depression filled with a pile at the pollex base in the male major claw (Fig. 5C, seta). This character is unique among Brazilian fiddler crabs. Otherwise, the general shape of carapace of M. victoriana is similar to M. rapax, M. burgersi and M. mordax.

\section{Subfamily Gelasiminae}

\section{Minuca vocator (Herbst, 1804)}

Figure 3A, B

Recognition characters. Carapace pentagonal moderately arched; profuse pile on dorsal surface forming a characteristic pattern mostly on hepatic and branchial regions (Fig. 3A). Dorso-lateral margins well marked even covered by pile, and strongly convergent posteriorly; major and minor pairs of postero-lateral striae clearly visible (Fig. $3 \mathrm{~A}$, setae). Front triangular and very wide measuring from $36 \%$ to $38 \%$ of the frontorbital breadth. Male major claw with manus covered with small tubercles dorsally and frontally and provided with a strong groove on dorsal margin usually filled with dirt; fingers thick and slightly flattened, and a little longer than manus; pollex and dactyl slightly curved forming a gap as wide as the fingers in their base. Exuberant piles on 
dorsal surface of merus, carpus and manus of all ambulatory legs; these piles can extend to ventral side of manus (Fig. 3B). Male abdomen somites never fused. Medium-sized crabs, males with CW up to $27.0 \mathrm{~mm}$ in a population from Itamambuca mangrove, Ubatuba, southeastern Brazil (Colpo and Negreiros-Fransozo 2004).

Biological notes. The species forms one of the densest populations composed by large crabs, and its reproductive period coincides with the rainy period in northern Brazil (Koch et al. 2005). The southeast populations, however, have continuous reproduction (Colpo and Negreiros-Fransozo 2003). On the other hand, in impacted mangroves of southeastern Brazil, populations are not dense and crabs are smaller than in other populations (Bedê et al. 2008). The species prefers muddy substrates (Colpo and Negreiros-Fransozo 2003; Thurman et al. 2013). Large and well-constructed chimneys at the entrance of burrows were observed in a population from Venezuela, but there is no record of this ornamentation in any other population including those from Brazilian coast (Crane 1975).

Remarks. Characteristic pubescence pattern on the carapace and dense piles on dorsal surface of ambulatory legs are the best diagnostic characters for distinguishing it from other Minuca species recorded in Brazil. Another Brazilian fiddler crab that has an exuberant pile on the carapace surface is Leptuca thayeri, easily distinguishable from M. vocator by a very narrow front of the former species (compare Figs $2 \mathrm{C}$ and $3 \mathrm{~A}$ ). Although Melo (1996) considered Santa Catarina State as the southernmost limit of the geographic distribution of the species, currently the species has been reported only in the states from Amapá to São Paulo (Table 1).

\section{Subfamily Gelasiminae}

\section{Leptuca cumulanta (Crane, 1943)}

Figures 9B, 10A, B

Recognition characters. Carapace semi-cylindrical, width ca. 1.6 times the length; strongly arched and dorsal surface without pile; lateral margins almost parallel (Fig. 10A). Dorso-lateral margins well marked and strongly converging posteriorly; single pair of postero-lateral striae clearly visible (Fig. 10A, seta). The discrete pile on the carapace described by von Hagen (1987) was not observed in the specimens examined in the present study. Front triangular and moderately wide measuring from $25 \%$ to $29 \%$ of the front-orbital breadth. Manus of male major claw with dorso-lateral surface covered by tubercles except along the strong dorsal groove (mostly filled with dirt); smooth surface in the submarginal longitudinal area; dorsal surface with sparse tubercles while dorso-lateral one with small and dense tubercles; fingers ca. 1.7 times the manus length; pollex almost straight but dactyl strongly arched ending in a curved downward tip, forming a very wide gap (Fig. 10B). Ambulatory legs without pile. Male abdomen somites distinct (Fig. 9B). Small crabs, males' CW up to $12.5 \mathrm{~mm}$ in a population from Caeté mangrove, Pará state, northern Brazil (Koch et al. 2005).

Biological notes. The species reproduces year-round in populations of northern Brazil and the crabs reach the largest CW among all other populations (Koch et al. 
2005). In the impacted mangroves, L. cumulanta is the fourth most abundant fiddler crab species, but crabs' CW is the smallest among these populations (Bedê et al. 2008). The species prefers muddy substrates (Thurman et al. 2013). Hoods at the entrance of male burrows were observed in some populations in Venezuela and Curaçao, but there is no such record from populations of the Brazilian coast (Crane 1975).

Remarks. In sympatric area of Brazilian coast $L$. cumulanta can be confused with L. leptodactyla (from Pará to Rio de Janeiro) and L. uruguayensis (Rio de Janeiro state): they are similar in size and the major male claw is provided with a very curved dactyl forming a wide gap with the pollex. The best ways to distinguish these three species is described when referring to L. leptodactyla and $L$. uruguayensis (see below).

\section{Subfamily Gelasiminae}

\section{Leptuca leptodactyla (Rathbun, 1898)}

Figures 9A, 11C, D

Recognition characters. Carapace semi-cylindrical, width ca. 1.7 times the length; strongly arched and dorsal surface without any pile or other ornaments; lateral margins almost parallel (Fig. 11C). Front triangular and moderately wide making up 20\% to $23 \%$ of the front-orbital breadth. Dorso-lateral margins well marked and converging posteriorly; short and single pair of postero-lateral striae clearly visible (Fig. 11C). Male major claw smooth, manus with dorsal margin lined up with minute tubercles; fingers very slender and long, dactylus ca. 1.7 times the manus length (Fig. 11D); pollex almost straight and dactyl strongly arched ending in a curved downward tip; very wide gap between fingers. Ambulatory legs with narrow segments and devoid of pile or other ornaments. Male abdomen with $3^{\text {rd }}$ to $6^{\text {th }}$ somites fused (Fig. 9A). Small crabs: male CW maximum $14.29 \mathrm{~mm}$ in a population from Itacuruçá mangrove, Sepetiba Bay, southeastern Brazil (Bedê et al. 2008).

Biological notes. One of the most common fiddler crabs in sandy substrate of estuarine intertidal zone, $L$. leptodactyla reproduces year-round in the population of Ceará state (Bezerra and Matthews-Cascon, 2007), but only in warmer months at the southern coast (Masunari 2012). During the reproductive period (September-March in Guaratuba Bay, Paraná state), males construct a typical hood by piling up sand beside the burrow entrance where they stay for usual waving (Masunari 2012). The species shows strong preference for sandy substrate of polyhaline areas (Masunari 2006), and its young individuals can find shelter in the shadow of cordgrasses (S. Masunari, pers. obs.).

Remarks. Leptuca leptodactyla may be confused with L. cumulanta at the coast from Pará to Rio de Janeiro states. These two species, however, can be distinguished by features of the male abdomen: the middle somites are fused in the former species (Fig. 9A), while in L. cumulanta all somites are distinct (Fig. 9B). Furthermore, L. leptodactyla may also be confused with Leptuca uruguayensis in the sympatric area (from Rio de Janeiro to Santa Catarina state), especially among juvenile specimens. The male major claw of $L$. uruguayensis, however, is provided with a strong groove parallel to the dorsal margin of the manus (even in juvenile specimens) (Fig. 11B, seta), while in $L$. leptodactyla this groove is absent (Fig. 11D). 


\section{Subfamily Gelasiminae}

\section{Leptuca thayeri (Rathbun, 1900)}

Figure 2C, D

Recognition characters. Carapace trapezoidal weakly arched and covered with exuberant pile (pubescence easily detached) (Fig. 2C, seta) and strongly converging posteriorly. Dorso-lateral margins well marked and also strongly converging posteriorly; major and minor pairs of postero-lateral striae clearly visible (Fig. 2C). Front triangular and narrow making up ca. $15 \%$ of the front-orbital breadth. Male major claw with manus provided with a strong groove on the dorsal surface; fingers cylindrical and smooth; dactyl almost straight in the proximal two-thirds and curving down toward pollex tip and provided with a short but strong groove on the dorsal surface usually filled with dirt; moderate gap between fingers (Fig. 2D). Ambulatory legs with wide merus ca. 3.3 times the width of proximal end of carpus; posterior surface of all segments (except dactyl) of ambulatory legs covered by pile. Male abdomen segments not fused. Medium-sized species: male CW measures up to $28.4 \mathrm{~mm}$ in the population from Formoso River mangrove, Pernambuco state, northeastern Brazil (Farias et al. 2014).

Biological notes. Populations living in the northeastern Brazilian coast reproduce only in the rainy season (Ceará state) (Bezerra and Matthews-Cascon 2007) or continuously (Pernambuco state) (Farias et al. 2014), and those from southeastern Brazil during the warmer months (São Paulo state) (Costa et al. 2006). The species prefers typically muddy mangrove substrates in mesohaline areas, and it is the only fiddler crab in Brazil that forms large populations in shaded areas of the mangrove forest in Guaratuba Bay, southern Brazil (Masunari 2006). Males and females of L. thayeri can construct year-round highly structured chimneys around the entrance of the burrows; among the burrow with chimneys recorded in the mangrove of Guaratuba Bay, $53.3 \%$ contained non-ovigerous females, $37.7 \%$ ovigerous females and only $9.0 \%$ males. Furthermore, the chimneys belonging to males had always a larger diameter and were lower than those of females' (T.F. Moreto, pers. comm.).

Remarks. This species is hardly confused with other species of Brazilian fiddler crabs, as it has a very narrow triangular front (see Fig. 2C). Furthermore, the carapace and the ambulatory legs are heavily covered with pile.

\section{Subfamily Gelasiminae}

\section{Leptuca uruguayensis (Nobili, 1901)}

Figure 11A, B

Recognition characters. Carapace semi-pentagonal strongly arched and dorsal surface without pile or other ornaments (Fig. 11A). Dorso-lateral margins well marked and converging posteriorly; short and single pair of postero-lateral striae clearly visible (Fig. 11A). Front triangular and moderately wide making up from $20.0 \%$ to $23.6 \%$ of the frontorbital breadth. Manus of male major claw with dorso-lateral surface covered by small 
tubercles except along the strong submarginal groove, mostly filled with dirt (Fig. 11B, seta); both edges of dorsal margin armed with lined up by tubercles; dactyl moderately long ca. 1.4 times the manus length; pollex almost straight but dactyl strongly arched ending in a curved downward tip, forming a wide gap. Ambulatory legs with narrow segments and without pile. Male abdomen with $4^{\text {th }}$ to $6^{\text {th }}$ somites fused. Small crabs: males with $\mathrm{CW}$ up to $12.0 \mathrm{~mm}$ in a population from Itacuruçá mangrove, Sepetiba Bay, southeastern Brazil (Bedê et al. 2008). Leptuca uruguayensis, however, can attain up to $19.5 \mathrm{~mm}$ CW in the population from Solís Grande River, Uruguay (Masunari et al. 2017).

Biological notes. The species reproduces year-round in southeastern (Costa et al. 2006) and southern coast (Martins and Masunari 2013). It tolerates a wide range of salinities and is recorded in sandy substrates with a high degree of organic matter (Masunari 2006). In environments where the mangrove forest is absent (such as in the Uruguayan coast), L. uruguayensis occurs in marginal lowlands of rivers that flow into estuaries.

Remarks. Leptuca uruguayensis can be confused with $L$. cumulanta and $L$. leptodactyla in Rio de Janeiro state coast (these species are sympatric) due to the small size attained by these three species. The easiest way to separate them is by observing the male abdominal segments: among these three species only $L$. cumulanta has all somites distinct (see Fig. 9B) while the other two species have middle somites fused (Fig. 9A). On the other hand, $L$. uruguayensis can be distinguished from L. leptodactyla, by having a deep groove (filled with dirt) on dorsal granulated surface of manus of male major claw (Fig. 11B); in contrast, L. leptodactyla has the major claw manus with bare surface (Fig. 11D). Furthermore, the carapace of $L$. uruguayensis is semi-pentagonal with dorso-lateral margins moderately converging posteriorly (Fig. 11A), while L. leptodactyla has a cylindrical carapace and dorso-lateral margins weakly converging posteriorly (Fig. 11C).

\section{Subfamily Ocypodinae}

\section{Uca maracoani (Latreille, 1802-1803)}

Figures $1 \mathrm{~A}, 2 \mathrm{~A}, \mathrm{~B}$

Recognition characters. Carapace trapezoidal moderately arched and naked dorsal surface, without any ornaments. Dorso-lateral margins well marked, long and weakly converging posteriorly; postero-lateral striae absent (Fig. 2A). Front spatulate and very narrow making up ca. 4\% of front-orbital breath (Fig. 1A). Male major claw extremely large, with flat fingers and ornamented with tubercles, granules and small patches; narrow gap (Fig. 2B). Ambulatory legs without pile. Male abdomen somites distinct. Large fiddler crab: male CW up to $45.0 \mathrm{~mm}$ and female $40.2 \mathrm{~mm}$ in Paraty Bay, Rio de Janeiro state, southeastern Brazil (Hirose and Negreiros-Fransozo 2008).

Biological notes. The species reproduces year-round in northern (Azevedo et al. 2016), northeastern (Silva et al. 2016), southeastern (Hirose and Negreiros-Fransozo 2008) and southern (Benedetto and Masunari 2009) regions, but only during the dry season in northern region (Koch et al. 2005). Well-established populations are typically recorded in muddy substrates of polyhaline areas of estuaries, where no other 
fiddler crab species was seen sharing this space (Masunari 2006). Genetic analysis revealed a lack of discernible genetic subdivision among populations of $U c a$ maracoani along Brazilian coast; however, geometric morphometric technique showed statistically significant morphological differentiation that would indicate a strong phenotypic plasticity (Wieman et al. 2014).

Remarks. In the field, these crabs are unmistakable recognizable by the flattened fingers of the male major claw. Furthermore, they are visibly larger than any other Brazilian fiddler crab species.

\section{Distribution}

Most Brazilian fiddler crabs occur along the coastal estuaries in environments closely related to mangroves that are distributed in the country from Amapá state to Laguna do Imaruí in the municipality of Laguna (20 30'S), Santa Catarina state (Vale and Schaeffer-Novelli 2018). Only Minuca mordax and Leptuca uruguayensis exceed southwards into estuarine areas where mangroves do not grow (Table 1). In Rio Grande do Sul state, where mangroves are absent, $M$. mordax lives on marginal banks of streams (S.B. Martins, pers. comm.), while in Uruguayan estuaries L. uruguayensis inhabit stream lowlands (Masunari et al. 2017).

We hypothesized that in Piauí State and others, where records of some common fiddler crab species are missing (Table 1, open circles), future collections will certainly fill the gaps. Only four species occur continuously in all states from Amapá to Santa Catarina (M. mordax, M. rapax, Uca maracoani and L. thayeri) while another two species are reported from Pará to Santa Catarina (L. leptodactyla and M. burgersi). Three species do not follow the entire distribution of mangroves $(M$. vocator from Amapá to São Paulo; L. cumulanta from Amapá to Rio de Janeiro, and L. uruguayensis from Rio de Janeiro to Rio Grande do Sul). The only remaining species (M. victoriana) has a restricted distribution and infrequent occurrence (Table 1).

\section{Acknowledgments}

We are grateful to Prof. Marcelo Antonio Amaro Pinheiro from Biosciences Institute of Sáo Paulo State University-UNESP for providing us specimens of the fiddler crabs $\mathrm{Mi}$ nuca victoriana and M. vocator, and for Prof. Luís Ernesto Arruda Bezerra from Marine Science Institute of the Federal University of Ceará for critical review. Thanks are also due to Prof. Luís Amilton Foerster from Zoology Department of Federal University of Paraná for the English revision. Some undergraduate students were invited to test the present key, to whom we are so grateful. All biological sampling of the present study complies with the current laws of Paraná State and Brazilian Federal Government, which was conducted with the permission of SISBIO (Authorization system and information on biodiversity license $\mathrm{N}^{\circ} 16140-1$ ). 


\section{References}

Azevedo DS, Silva JUCL, Castiglioni DS (2016) Population biology of Uca maracoani in a tropical mangrove. Thalassas 33: 1-13. https://doi.org/10.1007/s41208-015-0008-0

Baptista MB, Calado TCS (2007) Estrutura das populaçôes do gênero Uca (Crustacea, Decapoda, Ocypodidae) do Complexo Estuarino-Lagunar Mundaú/Manguaba, Maceió-AL. Anals of VIII Congress of Ecology of Brazil, September 2007. Brazilian Society of Ecology, Caxambu, Brazil, 1-2.

Bedê LM, Oshiro LMY, Mendes LMD, Silva AA (2008) Comparação da estrutura populacional das espécies de Uca (Crustacea: Decapoda: Ocypodidae) no Manguezal de Itacuruçá, Rio de Janeiro, Brasil. Revista Brasileira de Zoologia 25(4): 601-607. https://doi. org/10.1590/S0101-81752008000400004

Benedetto MD, Masunari S (2009) Estrutura populacional de Uca maracoani (Decapoda, Brachyura, Ocypodidae) no Baixio Mirim, Baía de Guaratuba, Paraná. Iheringia, Sér. Zoologia 99(4): 381-389. https://doi.org/10.1590/S0073-47212009000400007

Benetti AS, Negreiros-Fransozo ML, Costa TM (2007) Population and reproductive biology of the crab Uca burgersi (Crustacea: Ocypodidae) in three subtropical mangrove forests. Revista de Biología Tropical 55: 55-70. https://doi.org/10.15517/rbt.v55i0.5806

Bezerra LEA (2012) The fiddler crabs (Crustacea: Brachyura: Ocypodidae: genus Uca) of the South Atlantic Ocean. Nauplius 20(2): 203-246. https://doi.org/10.1590/S010464972012000200011

Bezerra LEA, Matthews-Cascon H (2007) Population and reproductive biology of the fiddler crab Uca thayeri Rathbun, 1900 (Crustacea: Ocypodidae) in a tropical mangrove from northeast Brazil. Acta Oecologica 31(3): 251-258. https://doi.org/10.1016/j.actao.2006.10.003

Castiglioni DS, Almeida A, Bezerra L (2010) More common than reported: range extension, size-frequency and sex-ratio of Uca (Minuca) victoriana (Crustacea: Ocypodidae) in tropical mangroves, Brazil. Marine Biodiversity Records 3: e94. https://doi.org/10.1017/ S1755267210000874

Castiglioni DS, Negreiros-Fransozo ML (2004) Comparative analysis of the relative growth of Uca rapax (Smith, 1870) (Crustacea Ocypodidae) from two mangroves in São Paulo Brazil. Revista Brasileira de Zoologia 21(1): 137-144. https://doi.org/10.1590/S010181752004000100023

Castiglioni DS, Negreiros-Fransozo ML (2006) Ciclo reprodutivo do caranguejo violinista Uca rapax (Smith, 1870) (Crustacea Ocypodidae), habitante de um estuário degradado em Paraty, Rio de Janeiro, Brasil. Revista Brasileira de Zoologia 23(2): 331-339. https://doi. org/10.1590/S0101-81752006000200004

Colpo KD, Negreiros-Fransozo ML (2003) Reproductive output of Uca vocator (Herbst, 1804) (Brachyura, Ocypodidae) from three subtropical mangroves in Brazil. Crustaceana 76(1): 1-11. https://doi.org/10.1163/156854003321672782

Colpo KD, Negreiros-Fransozo ML (2004) Comparison of the population structure of the fiddler crab Uca vocator (Herbst, 1804) from three subtropical mangrove forests. Scientia Marina 68(1): 139-146. https://doi.org/10.3989/scimar.2004.68n1139 
Costa T, Soares-Gomes A (2009) Population structure and reproductive biology of Uca rapax (Decapoda: Ocypodidae) in a tropical coastal lagoon, southeast Brazil. Zoologia 26(4): 647-657. https://doi.org/10.1590/S1984-46702009000400009

Costa TM, Silva SMJ, Negreiros-Fransozo ML (2006) Reproductive pattern comparison of Uca thayeri Rathbun, 1900 and U. uruguayensis Nobili, 1901 (Crustacea, Decapoda, Ocypodidae). Brazilian Archives of Biology and Technology 49(1): 117-123. https://doi. org/10.1590/S1516-89132006000100014

Crane J (1975) Fiddler crabs of the world Ocypodidae: Genus Uca. Princeton University Press, Princeton, $736 \mathrm{pp}$.

Farias ACA, Castiglioni DS, Garcia JE (2014) Population structure of the fiddler crab Uca thayeri Rathbun, 1900 (Crustacea, Decapoda, Ocypodidae) in a tropical mangrove. Thalassas 30(1): 21-37.

Hirose GL, Negreiros-Fransozo ML (2008) Population biology of Uca maracoani Latreille 1802-1803 (Crustacea, Brachyura, Ocypodidae) on the south-eastern coast of Brazil. PanAmerican Journal of Aquatic Sciences 3(3): 373-383.

Koch V, Wolff M, Diele K (2005) Comparative population dynamics of four fiddler crabs (Ocypodidae genus $U_{c a}$ ) from a north Brazilian mangrove ecosystem. Marine Ecology Progress Series 291: 177-188. https://doi.org/10.3354/meps291177

Martins SB (2018) Estratégia reprodutiva e variabilidade morfológica e genética dos caranguejos chama-maré Leptuca leptodactyla (Rathbun, 1898) e Minuca mordax (Smith, 1870) (Crustacea, Decapoda, Ocypodidae) ao longo da costa do Brasil. PhD thesis, Curitiba, Brazil: Federal University of Paraná.

Martins SB, Masunari S (2013) Temporal distribution in the abundance of the fiddler crab Uca (Leptuca) uruguayensis Nobili, 1901 (Decapoda: Ocypodidae) from Garças River mangrove, Guaratuba Bay, southern Brazil. Nauplius 21(2): 151-159. https://doi.org/10.1590/ S0104-64972013000200003

Martins SB, Marochi MZ, Masunari S (2016) Description of the first juvenile stage of the fiddler crab Minuca mordax (Smith, 1870) (Crustacea, Decapoda, Ocypodidae). Papéis Avulsos de Zoologia 56(14): 163-169. https://doi.org/10.11606/00311049.2016.56.14

Masunari S (2006) Distribuição e abundância dos caranguejos Uca Leach (Crustacea Decapoda Ocypodidae) na Baía de Guaratuba, Paraná, Brasil. Revista Brasileira de Zoologia 23(4): 901-914. https://doi.org/10.1590/S0101-81752006000400001

Masunari S (2012) Hood construction as an indication of the breeding period of the fiddler crab Uca (Leptuca) Leptodactyla Rathbun, 1898 (Decapoda, Ocypodidae) from Guaratuba Bay, southern Brazil. Crustaceana 85(10): 1153-1169. https://doi. org/10.1163/156854012X651277

Masunari S, Martins SB, Marochi MZ, Serra WS, Scarabino F (2017) Morphological variability in populations of the fiddler crab Leptuca uruguayensis (Nobili, 1901) (Crustacea, Decapoda, Ocypodidae) from South America. Brazilian Journal of Oceanography 65(3): 373-381. https://doi.org/10.1590/s1679-87592017136606503

Melo GAS (1996) Manual de identificação dos Brachyura (caranguejos e siris) do litoral Brasileiro. Editora Plêiade, São Paulo, 603 pp. 
Mendes VMT, Couto ECG (2001) A família Ocypodidae Rafinesque, 1815 (Crustacea: Decapoda: Brachyura) na costa sergipana. Revista Nordestina de Biologia 15(2): 27-40.

Pillon CF (2014) Diversidade de caranguejos e estrutura populacional de Uca cumulanta Crane, 1943 (Decapoda: Brachyura: Ocypodidae) em um manguezal do nordeste brasileiro. Master thesis, Santa Maria, Brazil: Federal University of Santa Maria.

Ribeiro FB, Bezerra LEA (2014) Population ecology of mangrove crabs in Brazil: sesarmid and fiddler crabs. In: Ardovini C (Ed.) Crabs: global diversity behavior and environmental threats. Nova Science Publishers, New York, 19-56.

Scalco ACS, Ramos CA, Boos H (2016) Estrutura populacional de Uca (Minuca) mordax (Smith, 1870) (Decapoda: Ocypodidae) em um sistema estuarino impactado no Sul do Brasil. Revista CEPSUL - Biodiversidade e Conservação Marinha 5: 17-28.

Shih H-T, Ng PKL, Davie PJF, Schubart CD, Türkay M, Naderloo R, Jones D, Liu M-Y (2016) Systematics of the family Ocypodidae Rafinesque, 1815 (Crustacea: Brachyura), based on phylogenetic relationships, with a reorganization of subfamily rankings and a review of the taxonomic status of $U_{c a}$ Leach, 1814, sensu lato and its subgenera. Raffles Bulletin of Zoology 64: 139-175.

Silva DJA (2019) Comunicação visual em caranguejos chama-marés: a influência das cores no contexto sócio-sexual. Master thesis, Natal, Brazil: Federal University of Rio Grande do Norte.

Silva FMRO, Ribeiro FB, Bezerra LEA (2016) Population biology and morphometric sexual maturity of the fiddler crab Uca (Uca) maracoani (Latreille, 1802) (Crustacea: Decapoda: Ocypodidae) in a semi-arid tropical estuary of northeastern Brazil. Latin American Journal of Aquatic Research 44(4): 671-682. https://doi.org/10.3856/vol44-issue4-fulltext-2

Thurman CL, Faria SC, McNamara JC (2013) The distribution of fiddler crabs (Uca) along the coast of Brazil: implications for biogeography of the western Atlantic coast. Marine Biodiversity Records 6: e1. https://doi.org/10.1017/S1755267212000942

Vale CC, Schaeffer-Novelli Y (2018) A zona costeira do Brasil e os manguezais. In: Atlas dos manguezais do Brasil. Instituto Chico Mendes de Conservação da Biodiversidade, Brasília, $37-56$.

von Hagen H-O (1987) Morphologie und Winkbalz einer neuen Uca-Art (Crustacea, Brachyura) aus dem Staat Espírito Santo (Brasilien). Mitteilungen aus den Hamburgischen Zoologischen Museum und Institut 84: 81-94.

Wieman AC, Berendzen PB, Hampton KR, Jang J, Hopkins MJ, Jurgenson J, McNamara JC, Thurman CL (2014) A panmictic fiddler crab from the coast of Brazil? Impact of divergent ocean currents and larval dispersal potential on genetic and morphological variation in Uca maracoani. Marine Biology 161(1): 173-185. https://doi.org/10.1007/s00227-013-2327-0 